\title{
Possibilities and limits of adhesive layer thickness optical evaluation
}

Müller Miroslav, Department of Material Science and Manufacturing Technology, Faculty of Engineering, Czech University of Life Science, Kamýcká 129, 165 21, Prague, muller@tf.czu.cz Náprstková Nataša, Department of Technologies and Material Engineering, Faculty of production Technology and Management, J. E. Purkyně University in Ústí nad Labem, Pasteurova 7, 400 01, Ústí nad Labem, naprstkova@fvtm.ujep.cz

The uniform adhesive layer thickness belongs to the key criterions of the bonded joint formation. On the basis of longterm laboratory findings it was evaluated as one of basic effects on the strength changes. This fact leads to the objective evaluation necessity and to the technical practice respecting. The carried out laboratory experiments are indicative of the incongruity between the expected adhesive layer thickness and the real value determined in the bonded joint square cut using the microscope.

Keywords: Adhesive bond, adhesive layer thickness, microscope

\section{References}

[1] ADAMS, R. D., COMYN, J., WAKE, W. C.: Structural adhesive joints in engineering. $2^{\text {nd }}$ ed. London: Chapman \& Hall, 1997. 376 p.

[2] BROŽEK, M., MÜLLER, M.: Mechanické vlastnosti spojů lepených sekundovými lepidly. Strojírenská technologie, 2004, vol. 9 , no. 1 , pp. $9-15$.

[3] CAGLE CH., V. et al.: Handbook of adhesive bonding. New York: MacGraw-Hill 1973. 680 p.

[4] GRANT, L. D. R. et al.: Experimental and numerical analysis of single-lap joints for the automotive industry. International Journal of Adhesion \& Adhesives, 2009, vol. 29, no. 4, pp. 405 - 413.

[5] HABENICHT, G.: Kleben: Gundlagen, Technologien, Anwendung. Berlin: Springer 2002. 921 p.

[6] HOLEŠOVSKÝ, F., NOVÁK, M.: Influence of grinding on machine parts with desing notches, Journal - Manufacturing Technology, 2009, vol 9, no: zvláštní číslo, pp. 40 - 46.

[7] HOLEŠOVSKÝ, F.: Stanovení zbytkových napětí v povrchu po obrábění. Strojírenská technologie, 2006, vol. 11, no. 3 , pp. $29-32$.

[8] KAŠPAR, Z.: Lepeni konstrukčních materiálů v zemědělství. Praha, 2005. 125 p. Doktorská disertační práce na Technické fakultě České zemědělské univerzity v Praze na Katedře materiálu a strojírenské technologie. Vedoucí doktorské disertační práce Doc. Ing. Milan Brožek, CSc.

[9] KOTOUSOV, A.: Effect of a thin plastic adhesive layer on the stress singularities in a bi-material wedge. International Journal of Adhesion \& Adhesives, 2007, vol. 27, no. 8, pp. 647 - 652.

[10] MESSLER, R. W.: Joining of materials and structures from pragmatic process to enabling technology. Burlington: Elsevier, 2004. 790 p.

[11] MÜLLER, M.: Lepení kovových a nekovových materiálio. Praha, 2006. 123 p. Doktorská disertační práce na Technické fakultě České zemědělské univerzity v Praze na Katedře materiálu a strojírenské technologie. Vedoucí doktorské disertační práce Doc. Ing. Milan Brožek, CSc.

[12] MÜLLER, M. et al.: Evaluation of factors influencing adhesive bond strength, Research in Agricultural Engineering. 2006, vol. 52, no. 1, pp. $30-37$.

[13] MÜLLER, M. et al.: Hodnocení vlivu integrity lepeného povrchu na změnu pevnostních charakteristik lepeného spoje, Strojírenská technologie, 2007, vol. 12, no. zvláštní číslo, pp. 177 - 180.

[14] MÜLLER, M., CHOTĚBORSKÝ R.: Možnosti hodnocení tloušt'ky lepené vrstvy, Jemná mechanika a optika, 2007, vol. 52 , no. 9 , pp. $247-249$.

[15] MÜLLER, M., BROŽEK, M.,: Technologie lepení - vliv expirační doby lepidel na pevnost lepených spojů. Strojírenská technologie, 2005, vol. 10, no. 3, pp. $10-16$.

[16] MÜLLER, M., CHOTĚBORSKÝ R., NÁPRSTKOVÁ, N.,: Možnosti hodnocení mechanické úpravy lepeného povrchu. Jemná mechanika a optika, 2006, vol. 51, no. 10, pp. $277-279$.

[17] OSTEN, M.: Práce s lepidly a tmely. Praha: Grada Publishing, 1996. 129 p.

[18] PETERKA, J.: Lepení konstrukčnich materiálů ve strojírenství. Praha: SNTL, 1980. 788 p. 
[19] SHIELDS, J.: Adhesives Handbook. London: Butterworths, 1970. 355 p.

Acknowledgement

Supported by Internal grant agency of Faculty of Engineering, Czech University of Life Sciences in Prague, Project No. 31140/1312/313117.

Reviews:

Prof. Iva Nová, MSc., Ph.D.

Prof. Bruno Sopko, MSc., Ph.D. 